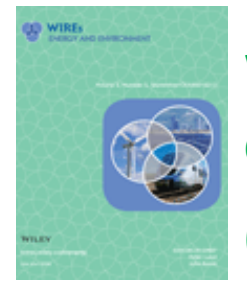

Wiley Interdisciplinary Reviews: Energy and Environment

Crop coefficients of Jatropha (Jatropha curcas) and Pongamia

(Pongamia pinnata) using water balance approach

Kaushal K. Garg, Suhas P. Wani*, A.V.R. Kesava Rao

International Crops Research Institute for the Semi Arid Tropics, Patancheru, Andhra Pradesh, India

DOI: http://dx.doi.org/10.1002/wene.88

This is author version post print archived in the official Institutional Repository of ICRISAT www.icrisat.org

Crop coefficients of Jatropha (Jatropha curcas) and Pongamia (Pongamia pinnata) using water balance approach

Kaushal K. Garg, Scientist, Suhas P Wani , Principal Scientist, A. V. R. Kesava Rao, Scientist

International Crops Research Institute for the Semi Arid Tropics, Patancheru 502 324, Andhra

Pradesh, India 


\begin{abstract}
Jatropha and Pongamia are potential source of bio-diesel and grow in a wide range of agro climatic zones and soil conditions. Data and knowledge available on water requirement of Jatropha and Pongamia are very scarce. Crop coefficients are important parameters used for assessing water requirement and irrigation scheduling. In present study, crop coefficients of Jatropha and Pongamia were estimated using water balance approach. Temporal data on soil moisture at different depths in block plantations of Jatropha and Pongamia at ICRISAT farm, Patancheru in India were collected at 15 days interval between 2007 and 2010. Measured soil moisture data were analyzed using one dimensional water balance model. Results showed that annual water requirement of Jatropha is 750 $\mathrm{mm}$ and of Pongamia is about $950 \mathrm{~mm}$ in semi-arid tropics. Crop-coefficients of Jatropha ranged from 0.10 to 0.95 and of Pongamia from 0.30 to 1.10 depending on plant growth stage in different months. ICRISAT received $820 \mathrm{~mm}$ of rainfall in a normal year (data between 2001 and 2010) during the monsoon, of which $52 \%$ (430 mm) contributed to evapo-transpiration, $34 \%$ ( $280 \mathrm{~mm}$ ) was stored in soil and, $14 \%$ (110 mm) was lost through surface runoff. Stored soil moisture during monsoon season was subsequently utilized by the Jatropha and $270 \mathrm{~mm}$ converted into ET during non-monsoonal period. Pongamia utilized stored soil moisture more effectively than Jatropha as it could remove water from deeper soil layers even at high levels of soil moisture suction.
\end{abstract}

Key words: Bio-diesel, Jatropha, Pongamia, Green water, Semi arid tropics, Water Impact Calculator

\title{
INTRODUCTION
}

Food and energy security are becoming a major issue both for developing and developed countries all over the world. Biofuel such as ethanol and bio-diesel are considered as one of the potential alternatives to reduce fossil fuel dependency ${ }^{1,2}$, also to reduce greenhouse gas emission and to sequester carbon ${ }^{2,3,4}$. In recent years, governments of many countries have targeted use of biofuel by blending it with conventional petroleum fuel and are promoted for wide industrial adaptability ${ }^{1,5}$. In contrary, it is also hypothesized that biofuel production at large scale may threaten the food security by competing with food crops and thus affecting the food supply and prices ${ }^{6,7}$. On the other hand, production of bio-diesel from plants grown in degraded lands offers opportunities to address the issues of environmental protection and provide options for improving rural livelihood especially in developing countries ${ }^{3,8,9}$. Jatropha curcas (Jatropha) and Pongamia pinnata (Pongamia) are identified as potential bio-diesel crops and may be grown in marginal and degraded lands with a wide range of rainfall and ecological conditions $^{4,10,11,12}$. 
Although, the demand for bio-diesel is increasing, available data and knowledge on yield potential and water requirement of Jatropha and Pongamia are very limited and thus research efforts are required to address such issues ${ }^{13}$. However, few estimates on water requirements of Jatropha have been reported in literatures. For example, Rao et al. ${ }^{14}$ reported that evapotranspiration (ET) from Jatropha plantation ranges from 1410 to $1538 \mathrm{~mm}$ in optimal conditions and $614-930 \mathrm{~mm}$ in field conditions in a semi-arid tropical location in India. They observed moisture extraction from soil layers $150 \mathrm{~cm}$ below from surface by five year old plants. Transpiration requirement of Jatropha was estimated as $300 \mathrm{~mm}$ and $500 \mathrm{~mm}$ at $4^{\text {th }}$ and $12^{\text {th }}$ year of growth stage at Owen Sithole College of Agriculture near Empangeni on the KZN north coast and Makhathini, Southern Africa, respectively ${ }^{15}$. Gush and Moodley ${ }^{16}$ estimated total transpiration of $1983 \mathrm{e}(147 \mathrm{~mm})$ for a 4-year-old J. curcas tree grown at a relatively wetter location, and $4884 \mathrm{e}(362 \mathrm{~mm})$ for a 12-year-old J. curcas tree grown at a dry site of South Africa. Transpiration rate was found high during the warm wet summer months and negligible during winter due to the deciduous nature of the Jatropha species.

Water requirement of a plant may be estimated by multiplying crop coefficients $\left(K_{c}\right)$ with atmospheric water demand $\left(\mathrm{ET}_{0}\right)$. In this method, effect of crop transpiration and evaporation are integrated by a single coefficient, which is known as crop coefficient ${ }^{17}$. The $\mathrm{K}_{\mathrm{c}}-\mathrm{ET}_{0}$ approach provides a simple, convenient and reproducible way to estimate water requirement of crops in different climatic conditions $^{17,18}$. Crop coefficient values have been reported for several crops ${ }^{17}$ and tree plantations $s^{19,20}$ and have been widely used for irrigation scheduling ${ }^{17,21}$, simulation studies ${ }^{22}$ and decision making process $^{17}$.

Several methodologies were developed for estimating $K_{c}$, for example, weighing lysimeter based techniques $^{23}$, agronomic measurements ${ }^{18}$ and remote sensing-based techniques ${ }^{24}$. Irrespective to methodologies, basis for estimating $\mathrm{K}_{\mathrm{c}}$ in all such techniques is common i.e., computation of water and energy balance components. In the present study, we used soil moisture data collected at ICRISAT research station for analyzing water balance of Jatropha and Pongamia crops using one dimensional hydrological model. Specific objectives of the present study are: i) to estimate $\mathrm{K}_{\mathrm{c}}$ for Jatropha and Pongamia crops and ii) to assess water requirements and analyzing field water balance of Jatropha and Pongamia crops in semi-arid tropics. 


\section{MATERALS AND METHODS}

\section{Experimental setup and data monitoring}

International Crops Research Institute for the Semi-Arid Tropics (ICRISAT) is located at $17^{\circ} 53^{\prime} \mathrm{N}, 78^{\circ}$ $27^{\prime} \mathrm{E}$, and about $545 \mathrm{~m}$ above mean sea level in the Medak district of Andhra Pradesh, India. Climate of the study area is tropical monsoon. Long term (1974-2010) average annual rainfall is $898 \mathrm{~mm}$ (standard deviation, $\sigma=225 \mathrm{~mm}$ ), of which about $80-85 \%$ is received during June to October. Rainfall is highly erratic, both in terms of total amount and distribution over time. Monsoon is preceded by hot summers (minimum air temperature between $16^{\circ}$ and $29^{\circ} \mathrm{C}$ and maximum air temperature between $30^{\circ}$ and $43^{\circ} \mathrm{C}$ in May) and followed by cool winters (minimum air temperature in between $6^{\circ}$ and $20^{\circ} \mathrm{C}$ and maximum air temperature between $23^{\circ}$ and $32^{\circ} \mathrm{C}$ in December). Estimated potential Evapotranspiration (PET) of the study area is $1650 \mathrm{~mm}$ annually.

Two micro-watersheds each of 2 ha area were selected for cultivating Jatropha and Pongamia crops at ICRISAT research station, respectively. Soil of experimental site is classified as Vertisols having maximum depth up to $3 \mathrm{~m}$. Topography of micro-watersheds is relatively flat with average slope between 1.0 and $2.0 \%$. Soil physical and chemical properties of experimental site e.g. bulk density, texture, organic carbon and soil water retention parameters were measured. Mean values of soil organic carbon was $0.65 \%$ (standard deviation, $\sigma=0.2$ ) in $0-15 \mathrm{~cm}$ depth and $0.50 \%(\sigma=0.10)$ in $15-30 \mathrm{~cm}$ soil depth. Soil bulk density of upper soil layers is relatively higher $\left(1.4 \mathrm{~g} \mathrm{~cm}^{-3}\right.$ up to $75 \mathrm{~cm}$ layer) compared to lower layers $\left(1.2 \mathrm{~g} \mathrm{~cm}^{-3}\right.$ between 120 and $\left.150 \mathrm{~cm}\right)$. Bulk density of surface soil varied between 1.30 and 1.55 with average of $1.35 \mathrm{~g} \mathrm{~cm}^{-3}$ across the watersheds. Subsurface soils are high in clay content and hold more amount (soil moisture availability $=0.25 \mathrm{~g} / \mathrm{g}$ ) of soil moisture compared to shallow soils (soil moisture availability $=0.14 \mathrm{~g} / \mathrm{g}$ ).

Jatropha ( $3 \mathrm{~m} \times 2 \mathrm{~m}$ spacing) and Pongamia (5 m $\times 5 \mathrm{~m}$ spacing) seedlings were planted in year 2004 . Crops were grown under rainfed conditions and chemical fertilizers were applied every year according to need of plants at its different growth stages. Nitrogen and phosphorus was applied @76 kg ha ${ }^{-1}$ and $10 \mathrm{~kg} \mathrm{ha}^{-1}$, respectively during 2006 and 2007. During subsequent growth stages, fertilizers dose was increased. Nitrogen and phosphorus was applied @ $92 \mathrm{~kg} \mathrm{ha}^{-1}$ and $50 \mathrm{~kg} \mathrm{ha}^{-1}$, respectively during 2008 and 2009 Source of $\mathrm{N}$ and $\mathrm{P}$ in above fertilization was urea and single super phosphate, respectively ${ }^{14}$. Total 12 neutron probe tubes in each of Jatropha and Pongamia micro-watersheds were installed for monitoring soil moisture content. Schematic layout of the experimental setup is shown in Figure $\mathbf{1}$ 
describing spacing and location of neutron probe tubes between the plants rows. Soil moisture content of each $15 \mathrm{~cm}$ thick layer was monitored from surface to $225 \mathrm{~cm}$ depth using calibrated neutron probe (Troxler 4302) at 15 days interval between 2007 and 2010. In addition, moisture in surface soils (0-15 and $15-30 \mathrm{~cm}$ ) was also measured by gravimetric method. Daily weather data (rainfall, maximum temperature, minimum temperature, wind speed, solar radiation, relative humidity, and pan evaporation) of experimental site were collected from meteorological station located at $200 \mathrm{~m}$ distance from the micro-watersheds. Data on agronomic growth, seed yield and oil content were measured both from the Jatropha and Pongamia fields.

\section{Description of simulation model}

A simple and one dimensional hydrological model (Water Impact Calculator, WIC developed in ICRISAT) was used to analyze field water balance in the present study. WIC requires data on soil (soil depth and water retention), weather (reference evapotranspiration and rainfall), crop growth (biomass and root growth function), topography (land slope, land form conditions), ex-situ interventions (water harvesting capacity) and crop management (date of crop sowing and harvesting irrigation method) as an input. WIC analyzes water balance on daily time scale for each one $\mathrm{cm}$ soil layer (generate simulation matrix: time vs. soil depth). Rainfall, which is the only source of water for rainfed situation was partitioned into several hydrological components as defined by following mass balance equation:

Rainfall $=$ Surface runoff + Deep percolation + Evapotranspiration (Evaporation + Transpiration) + Change in soil moisture storage

Eq.1

Surface runoff is the flow of excess rainwater after soil becomes saturated and generally occurs either during or after the rainfall event. The SCS curve number technique ${ }^{25}$ was used to estimate surface runoff in WIC. WIC calculates daily curves number value based on antecedent moisture content of surface soil layer (assumed for $15 \mathrm{~cm}$ depth in current analysis) and partition rainfall into surface runoff. Excess amount of infiltrated water after satisfying soil storage capacity is percolated below the crop root zone and is defined as deep percolation. Evapotranspiration comprises two basic hydrological processes: evaporation and transpiration. WIC calculates evaporation and transpiration based on imposed surface boundary conditions and moisture accessibility from surface soil layer and root zone. Water available in top $10 \mathrm{~cm}$ soil layer is contributed towards the evaporation demand, whereas, moisture available in root zone is used to meet crop water demand as defined by Allen et al. ${ }^{17}$. Crop water requirement (CWR) for a given crop is calculated such as: 
$C W R=K_{C} \times E T_{0}$

if : $\sum_{i=1}^{\text {rootzone }} A W C>C W R$ then $\mathrm{E} T=C W R$

otherwise $\mathrm{E} T=\sum_{i=1}^{\text {rootzone }} A W C$
Eq. 2

Eq. 3

where AWC is available water and $i$ denotes each $\mathrm{cm}$ increment in soil layer reaching up to root zone. It was further assumed that evaporation from soil surface is inversely proportional to vegetative growth/stage. Thus, after achieving full vegetative crop growth $(K c \geq 1.0)$, evaporation from the soil surface is considered almost negligible. Detailed description of WIC, model development, testing and validation procedure are shown by Garg et al. ${ }^{26}$

\section{Estimation of crop coefficients}

According to FAO-56 nomenclature, $K c$ calculates water requirements under growing conditions having a high level of management and with little or no water stress ${ }^{17}$. Appropriate corrections need to be incorporated while estimating crop coefficients in case of water stress situation due to less water uptake. Allen et al. ${ }^{17}$ described the effects of soil water stress on crop evapotranspiration (ETc) by multiplying the crop coefficient $(K c)$ and the water stress coefficient $(\mathrm{Ks})$ with $\mathrm{ET}_{0}$ such as: $\mathrm{ETc}=\mathrm{Ks} \mathrm{x} \mathrm{Kc}$ ETo

Eq. 4

Soils of the experimental watershed are characterized by Vertisols which has medium to high water holding capacity and average depth of 2.5-3.0 m. In current study, $K c$ is estimated under the fully developed stage (between 2007 and 2011) and is expected to experience with minimal water stress situation. Despite this, whenever available soil moisture depleted below the threshold limit, stress adjustment in ETc was made as defined by Allen et $a l^{17}$ and $K c$ was estimated using Eq. 4. Seventy per cent of total available water (soil moisture) is considered as readily available for crop uptake and further it declined linearly. Water stress coefficient (Ks in Eq.4) is assumed 0.7 for Jatropha and Pongamia as both are stress tolerant and deep rooted trees ${ }^{17,27,28,29}$. Crop coefficient of Jatropha and Pongamia crops were estimated using the inverse optimization technique. Solver is an optimization program built in Microsoft excel (developed for mixed integer nonlinear parameterization) was used for the current study. Based on field measurements, field capacity and permanent wilting point are defined for every 15 $\mathrm{cm}$ soil layer up to $300 \mathrm{~cm}$ depth. Maximum root zone depth for Jatropha and Pongamia plant is 
considered as $150 \mathrm{~cm}$ and $250 \mathrm{~cm}$, respectively. ${ }^{27,28,29}$ Model is set by assigning atmospheric boundary condition (rainfall and PET) on the soil surface as upper boundary and deep percolation from the bottom layer as the lower boundary. Simulation period is started after the four years of plant establishment. Total soil moisture status in root zone was used as the auxiliary variable in the objective function and crop coefficient at different crop growth stages were estimated using inverse optimization technique. WIC performance was assessed by comparing the simulated and measured soil moisture content using the root-mean-squared error (RMSE) of prediction:

$$
R M S E=\sqrt{\frac{1}{n} \sum_{i=1}^{n}\left(x_{i}-y_{i}\right)^{2}} \quad \text { Eq. } 5
$$

where $n$ is the number of data points of measured $\left(x_{i}\right)$ and simulated $\left(y_{i}\right)$ profile soil moisture.

\section{Estimation of crop water balance}

The calibrated model set-up was used to simulate water balance of 10-year time period between 2001 and 2010 capturing large variability of rainfall. Water balance components (ET, runoff and soil moisture) are derived for dry, normal and wet years according to following classification (India Meteorological Department, Pune, India; http://www.imdpune.gov.in): Rainfall less than $20 \%$ of the long-term average $=$ dry; Rainfall between $-20 \%$ to $+20 \%$ of the long-term average $=$ normal; Rainfall greater than $20 \%$ of long-term average $=$ wet.

Model further was used to estimate ET under non-limiting water stress situation both for Jatropha and Pongamia crops by applying auto irrigation setting in WIC between 2001 and 2010. Crop water stress was analyzed by considering difference between actual ET and ET under non-limiting water condition such as:

Water Stress Factor $(-)=1-\frac{\text { ET actual }}{\text { ET under Non limiting water situtation }} \quad$ Eq. 6

\section{RESULTS AND DISCUSSION}

\section{Variation of soil moisture in Jatropha and Pongamia watersheds}

Soil moisture variation in block plantations of Jatropha and Pongamia are depicted in Figures $\mathbf{2} \mathbf{a}$ and $\mathbf{2} \mathbf{b}$, respectively. Figures are divided into four panels and each one shows moisture profile of three consecutive months. In Jatropha field, new leaf flushes and biomass growth started by beginning of 
April; flowering initiated by May/June; and pod formation and harvesting stage occurred between September and December ${ }^{14}$. Previous stored soil moisture into subsurface layers was used by Jatropha plants to fulfill water requirements during leaf sprouting. Thus, moisture level depleted significantly between April and June (Figure 2a). Large variation in moisture profile is observed between July and September, as this period coincided with peak vegetative growth and occurrence of monsoonal rainfall. Total soil moisture was found highest during September. Moisture in soil profile is depleted slightly during pod formation and harvesting stage during November/December. Variation in profile moisture was found minimal between January and March because crop entered into dormancy phase and leaf started falling down (Figure 2a). Soil moisture fluctuation generally was found up to $150 \mathrm{~cm}$ indicating maximum effective rooting depth for Jatropha crop. ${ }^{27}$

In Pongamia field, low variation in moisture profile was observed during April and June, indicating lesser water uptake (Figure $\mathbf{2 b}$ ). Soil moisture content was increased during monsoon season and depleted subsequently in non-monsoonal period as expected. Data showed that Pongamia being a perennial crop could extract water from deeper and drier soil conditions. Several other studies indicated that Pongamia has an extensive lateral root system and thick-long tap $\operatorname{root}^{28}$, which could be developed maximum up to 5-10 m length at fully matured stage ${ }^{29}$. Soil moisture level in Pongamia cultivated field is depleted much higher compared to Jatropha cultivated fields. For example, soil moisture content for Jatropha and Pongamia cultivated field in month of May-June was recorded as $0.2-0.3 \mathrm{~cm}^{3} \mathrm{~cm}^{-3}$ and $0.03-0.15 \mathrm{~cm}^{3} \mathrm{~cm}^{-}$ ${ }^{3}$, respectively.

\section{Model performance}

Soil moisture measured in Jatropha and Pongamia fields is compared with model simulated moisture level between 2007 and 2011. Simulated soil moisture fluctuations are found comparable with observed numbers at most of the times both for Jatropha and Pongamia cultivated fields. Root mean square error in estimating profile moisture is $6.0 \mathrm{~cm}$ and $5.0 \mathrm{~cm}$, which is equivalent to less than $10 \%$ of total moisture in given soil profiles, thus model performance is considered acceptable.

\section{Crop coefficients and crop water requirements}

Crop coefficients estimated for Jatropha and Pongamia crops are summarized in Table $1 . K_{c}$ for Jatropha and Pongamia are found in range between 0.10-0.95 and 0.30-1.10, respectively. Maximum $\mathrm{K}_{\mathrm{c}}$ was found during August and September for both the crops. 
Water balance components of Jatropha and Pongamia fields are summarized in Table 2. During normal years, rainfall recorded was $911 \mathrm{~mm}$ ( $820 \mathrm{~mm}$ in monsoon and $91 \mathrm{~mm}$ in non-monsoon) at experimental site. In these years, ET from Jatropha and Pongamia crop were estimated to be 685 and $830 \mathrm{~mm} \mathrm{year}^{-1}$, respectively. Surface runoff generated from both the crop lands is found almost similar, i.e., 130-135 $\mathrm{mm}$ (15\% of total rainfall). In Jatropha field, nearly $100 \mathrm{~mm}$ rainfall was harvested in terms of green water. In Pongamia fields, $35 \mathrm{~mm}$ of net deficit in green water storage was observed by end of the crop season in normal years.

ET from Jatropha and Pongamia field was found larger than the rainfall received during dry years. About, 130-150 mm harvested green water in previous years was utilized by crops during dry years as shown by negative balance (Table 2). Surface runoff and deep percolation volume were estimated to be 90-100 $\mathrm{mm}$, i.e., $14 \%$ of rainfall received. Results showed that poor rainfall in dry years led to develop water shortage by $21 \%$ (in terms of ET) than the required quantity for Pongamia crop (shown by water stress factor in Table 2). On the other hand, crop water demand and availability for Jatropha crop was found in comparable range.

To show a detail description of mass balance, the monthly water balance of Jatropha and Pongamia field is presented for one of the selected normal year (Figure 3). Total $850 \mathrm{~mm}$ of rainfall was received during monsoon in year 2003. Thirty four per cent of monsoonal rain was captured as soil moisture, $52 \%$ (440 $\mathrm{mm})$ contributed to ET and $14 \%(120 \mathrm{~mm})$ was exported as surface runoff. In non-monsoon period (Nov-May), harvested green water acted as source of water as shown in Figure 3. Results showed that water requirements of both the crops were nearly same during monsoon period $(460 \mathrm{~mm})$ but Pongamia required additional $200 \mathrm{~mm}$ water during non-monsoon season compared to Jatropha (240 $\mathrm{mm}$ ). June is found the critical period for Jatropha growth and supplemental irrigation could be helpful in dry years.

\section{Conclusions}

Jatropha and Pongamia are potential bio-diesel crops and could be grown in wide range of agro-climatic and soil conditions. Water requirement of these two crops are estimated in the current study. Key findings of this study are:

1. Water requirements of Jatropha and Pongamia are estimated to be 750 and $950 \mathrm{~mm}$ in semiarid tropics, respectively. Water balance showed that at ICRISAT out of $820 \mathrm{~mm}$ rainfall received 
during monsoon period, $52 \%$ was contributed to ET, $34 \%$ stored as soil moisture and $14 \%$ exported outside from watershed as surface runoff. Consumptive water use by Jatropha and Pongamia are found to be nearly same in monsoon, i.e., 460-500 $\mathrm{mm}$. Water requirement (ET) of Jatropha during non-monsoon period is found as $265 \mathrm{~mm}$. Pongamia required $200 \mathrm{~mm}$ additional water than Jatropha during non-monsoonal period.

2. Crop coefficients of Jatropha and Pongamia ranged from 0.10-0.95 and 0.30-1.1 depending on growth stage, respectively. Pongamia is found to utilize green water from deeper and drier soil layers compared to Jatropha crop.

3. Water availability for Pongamia crops was found adequate in wet years but slightly less (10\% shortage) in normal year. Poor rainfall in dry years led to develop water shortage by $20 \%$ than the required quantity in Pongamia field, whereas Jatropha experienced negligible water stress in all the years. In-situ moisture availability played an important role in supplying water both for Jatropha and Pongamia crops especially in non-monsoon period.

Crop coefficient estimated in current study could be useful to assess technical feasibility to grow Jatropha and Pongamia crops in different agro-ecological regions and soil conditions.

\section{References}

1. Government of India. National Policy on Biofuels. Ministry of New \& Renewable Energy 2009 New Delhi.

2. Achten WMJ, Maes WH, Aerts R, Verchot L, Trabucco A, Mathijs E, Singh VP, Muys B. Jatropha: From global hype to local opportunity. Journal of Arid Environments 2010, 74:164-165.

3. Wani SP, Sreedevi TK, Marimuthu S, Rao AVRK, Vineela C. Harnessing the potential of Jatropha and Pongamia plantations for improving livelihoods and rehabilitating degraded lands. 6th International Biofuels Conference 2009, March 4-5, New Delhi, India.

4. Wani SP, Chander G, Sahrawat KL, Rao CS, Raghvendra G, Susanna P, Pavani M. Carbon sequestration and land rehabilitation through Jatropha curcas (L.) plantation in degraded lands. Agriculture, Ecosystems and Environment 2012, 161: 112- 120.

5. EC. Communication from the European Commission on An EU Strategy for Biofuels, COM 2006, 34 final. European Commission,

6. Doornbosch R, Steenblik R. Round Table on Sustainable Development Biofuels: Is the cure worse than the disease? Organization for Economic Cooperation and Development (OECD) 2007, 11-12 September.

7. Naylor R, Steinfield H, Falcon W, Galloway J, Smil V, Bradford E, Alder J, Mooney H. Losing the Links between Livestock and Land. Science 2007, 310: 1621-1622.

8. Wani SP, Sreedevi TK. Pongamia's journey from forest to microenterprise for improving livelihood, International Crop Research Institute for the Semi-Arid Tropics. Research Report 2005 Global Theme of Agroecosystems, Patancheru, India. 
9. Sreedevi TK, Wani SP, Srinivasa Rao CH, Chaliganti R, Reddy RL. Jatropha and Pongamia rain-fed plantations on wastelands in India for improved livelihoods and protecting environment. 6th International Biofuels Conference 2009, March 4-5 New Delhi, India.

10. Wani SP, Osman M, D'Silva E, Sreedevi TK. Improved livelihoods and environmental protection through biodiesel plantations in Asia. Asian Biotechnology and Development Review 2006 8(2): 11-29.

11. Achten WMJ, Verchot L, Franken YJ, Mathijs E, Singh VP, Aerts R. Review: Jatropha bio-diesel production and use. Biomass \& Bioenergy 2008, 32: 1063-1084.

12. Garg KK, Karlberg L, Wani SP, Berndes G. Jatropha production on wastelands in India: opportunities and trade-offs for soil and water management at the watershed scale. Biofuels, Bioproducts \& Biorefining 2011, 5: 410-430.

13. Raju KV. Biofuels in South Asia: An overview, editorial introduction. Asian Biotechnology and Development Review 2006: 8(2): 1-9.

14. Rao AVRK, Wani SP, Singh P, Srinivas K, Srinivasa Rao Ch. Water requirement and use by Jatropha curcas in a semi-arid tropical location. Biomass \& Bioenergy 2012, 39: 175-181.

15. Holl MA, Gush MB, Hallowes J, Versfeld DB. Jatropha curcas in South Africa: An Assessment of its Water Use and Bio-Physical Potential. Report submitted to the Water Research Commission on the project "Investigation into the Impacts of Large-Scale Planting of Jatropha curcas on Water Resources, through Process-Based Research and Modelling". WRC Report No 1497/1/07, NOVEMBER 2007.

16. Gush MB and Moodley M. Water use assessment of Jatropha curcas. In: Holl M, Gush MB, Hallowes J and Versfeld DB (eds.) Jatropha curcas in South Africa: An Assessment of its Water Use and BioPhysical Potential. WRC Report No. 1497/1/07 (Chapter 4). Water Research Commission, Pretoria, RSA

17. Allen RG, Pereira LS, Raes D, Smith M. Crop evapotranspiration: Guidelines for computing crop water requirements, Irrigation and Drainage Paper 56. United Nations FAO, Rome, 300 p. http://www.fao.org/docrep/X0490E/X0490E00.htm 1998

18. Allen RG, Pereira LS. Estimating crop coefficients from fraction of ground cover and height. Irrigation Science 2009, 28: 17-34.

19. Teixeira AH, de C, Bastiaanssen GM, Moura MSB, Soares JM, Ahmad MD, Bos MG. Energy and water balance measurements for water productivity analysis in irrigated mango trees, Northeast Brazil. Agricultural and Forest Meteorology 2008, 148: 1524-1537.

20. Paco TA, Ferreira MI, Rosa RD, Paredes P, Rodrigues GC, Conceicao N, Pacheco CA, Pereira LS. The dual crop coefficient approach using a density factor to simulate the evapotranspiration of a peach orchard: IMDualKc model versus eddy covariance measurements. Irrigation Science 2012, 30: 115-126.

21. Chen F, Robinson PJ. Estimating reference crop evapotranspiration with ET gauges. Journal of Irrigation and Drainage Engineering 2009, 135 (3): 335-342.

22. Cancela JJ, Cuesta TS, Neira XX, Pereira LS. Modelling for improved irrigation water management in a temperate region of Northern Spain. Biosystems Engineering 2006, 94(1): 151-163. 
23. Evett SR, Mazahrih NT, Jitan MA, Sawalha MH, Colaizzi PD, Ayars JE. A weighing lysimeter for crop water use determination in the Jordan Valley, Jordan, Transactions of the ASABE 2009, 52(1):155-169.

24. Singh RK, Irmak A. Estimation of Crop Coefficients Using Satellite Remote Sensing. Journal of Irrigation and Drainage Engineering 2009, 135: 597-608.

25. USDA-SCS. 1985. National Engineering Handbook, Section 4 - Hydrology. Washington, D.C.: USDASCS.

26. Garg KK, Wani SP, Patil MD. Simple and farmer-friendly decision support system for enhancing water use efficiency in agriculture: tool development, testing and validation. Submitted to "Agricultural water management" 2013.

27. Krishnamurthy L, Zaman-Allah M, Marimuthu S, Wani SP, Rao AVRK. Root growth in Jatropha and its implications for drought Adaptation. Biomass \& Bioenergy 2012, 39: 247-252.

28. Scott P T, Pregelj L, Chen N, Hadler J S, Djordjevic M A, Gresshoff P M. Pongamia pinnata: An Untapped Resource for the Biofuels Industry of the Future Bioenerg. Res 2008 1:2-11

29. Rangan L. Pongamia - A multipurpose versatile legume Research Journal of Biotechnology 2013. 8(1): 1-3.

\section{List of Tables}

Table 1: Crop coefficient for Jatropha and Pongamia tree crops on monthly time scale

\begin{tabular}{|c|c|c|}
\hline Month & $\mathbf{K}_{\mathbf{c}}$ of Jatropha & $\mathbf{K}_{\mathbf{c}}$ of Pongamia \\
\hline April & 0.20 & 0.30 \\
\hline May & 0.40 & 0.40 \\
\hline June & 0.60 & 0.40 \\
\hline July & 0.85 & 0.70 \\
\hline August & 0.90 & 0.90 \\
\hline September & 0.95 & 1.10 \\
\hline October & 0.80 & 1.10 \\
\hline November & 0.70 & 1.10 \\
\hline December & 0.50 & 0.75 \\
\hline January & 0.30 & 0.65 \\
\hline February & 0.10 & 0.60 \\
\hline March & 0.10 & 0.35 \\
\hline
\end{tabular}


Table 2: Water balance of Jatropha and Pongamia cultivated fields at ICRISAT for 10 years simulation period

\begin{tabular}{|c|c|c|c|c|c|c|c|c|c|}
\hline \multirow{3}{*}{$\begin{array}{c}\text { Crop } \\
\text { cultivated }\end{array}$} & \multirow{3}{*}{ Year } & \multirow{3}{*}{$\begin{array}{c}\text { No } \\
\text { of } \\
\text { year }\end{array}$} & \multicolumn{6}{|c|}{ Water balance components } & \multirow{3}{*}{$\begin{array}{c}\text { Water } \\
\text { stress } \\
\text { factor } \\
(-)\end{array}$} \\
\hline & & & \multicolumn{3}{|c|}{ Rainfall (mm) } & \multirow{2}{*}{$\begin{array}{c}\text { Surface } \\
\text { runoff + } \\
\text { Deep } \\
\text { percolation } \\
(\mathrm{mm}) \\
\end{array}$} & \multirow{2}{*}{$\begin{array}{c}\text { ET } \\
(\mathrm{mm})\end{array}$} & \multirow{2}{*}{$\begin{array}{c}\text { Change } \\
\text { in SMC } \\
(\mathrm{mm})\end{array}$} & \\
\hline & & & $\begin{array}{l}\text { Jun- } \\
\text { Oct }\end{array}$ & $\begin{array}{l}\text { Oct- } \\
\text { May }\end{array}$ & $\begin{array}{l}\text { Annual } \\
\text { rainfall }\end{array}$ & & & & \\
\hline Jatropha & Dry & 2 & 612 & 40 & 652 & 90 & 690 & -128 & 0.01 \\
\hline Jatropha & Normal & 6 & 820 & 91 & 911 & 130 & 700 & 80 & 0.01 \\
\hline Jatropha & Wet & 2 & 1179 & 71 & 1250 & 322 & 808 & 118 & 0.00 \\
\hline Pongamia & Dry & 2 & 612 & 40 & 652 & 95 & 710 & -153 & 0.21 \\
\hline Pongamia & Normal & 6 & 820 & 91 & 911 & 115 & 830 & -35 & 0.10 \\
\hline Pongamia & Wet & 2 & 1179 & 71 & 1250 & 249 & 953 & 48 & 0.00 \\
\hline
\end{tabular}

The calibrated model set-up is used to simulate water balance for a 10-year time period between 2001 and 2010. Water balance results are presented for dry, normal and wet years according to following classification (Indian Meteorological Department, Pune, India; http://www.imdpune.gov.in): Rainfall less than $20 \%$ of the long-term average $=$ dry; Rainfall between $-20 \%$ to $+20 \%$ of the long-term average $=$ normal; Rainfall greater than $20 \%$ of long-term average $=$ wet; 


\section{List of Figures}

Layout of neutron probe access tubes for soil moisture measurement

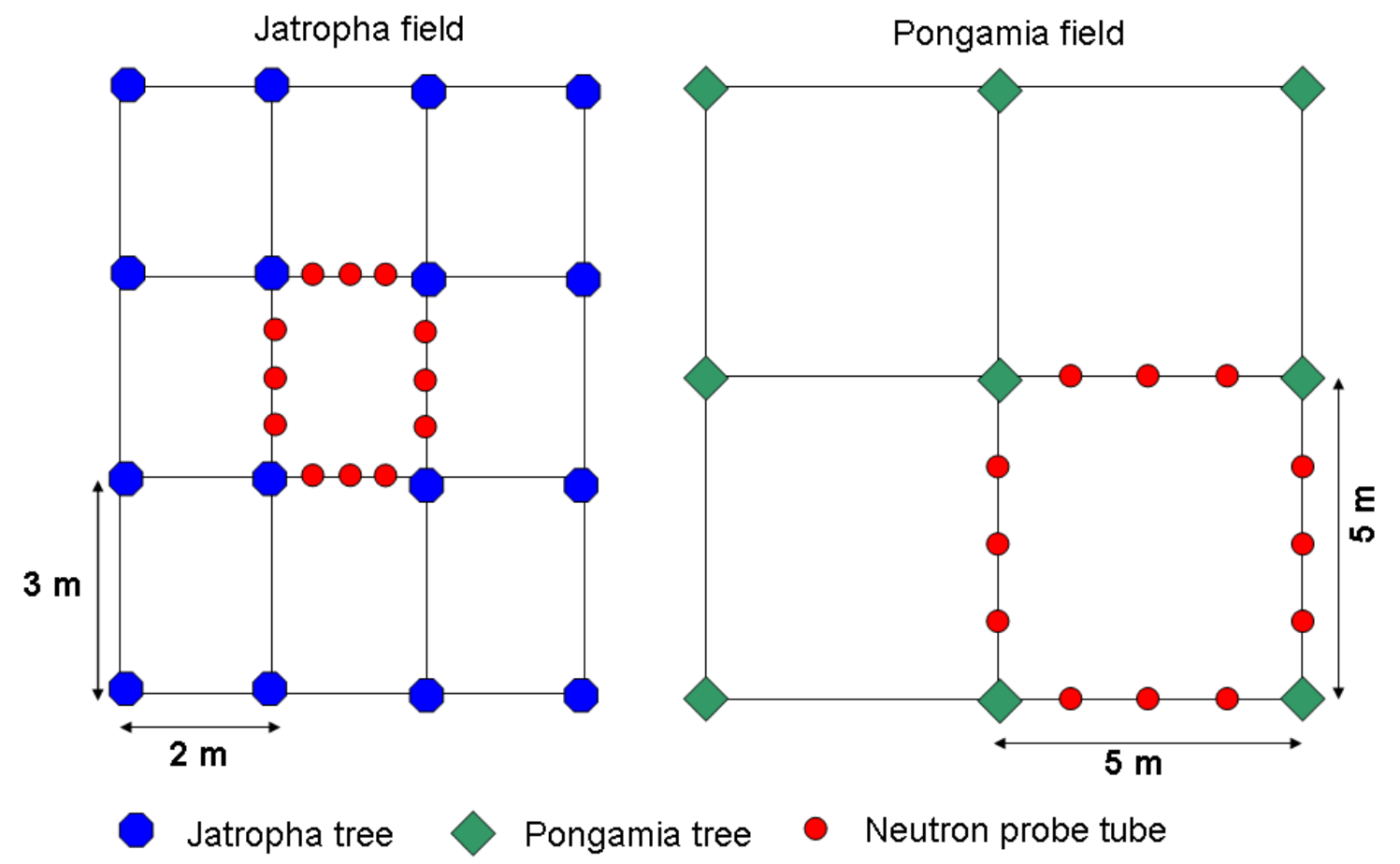

Figure 1: Layout of neutron probe access tubes for soil moisture measurement in Jatropha and Pongamia field at ICRISAT, Patancheru. 


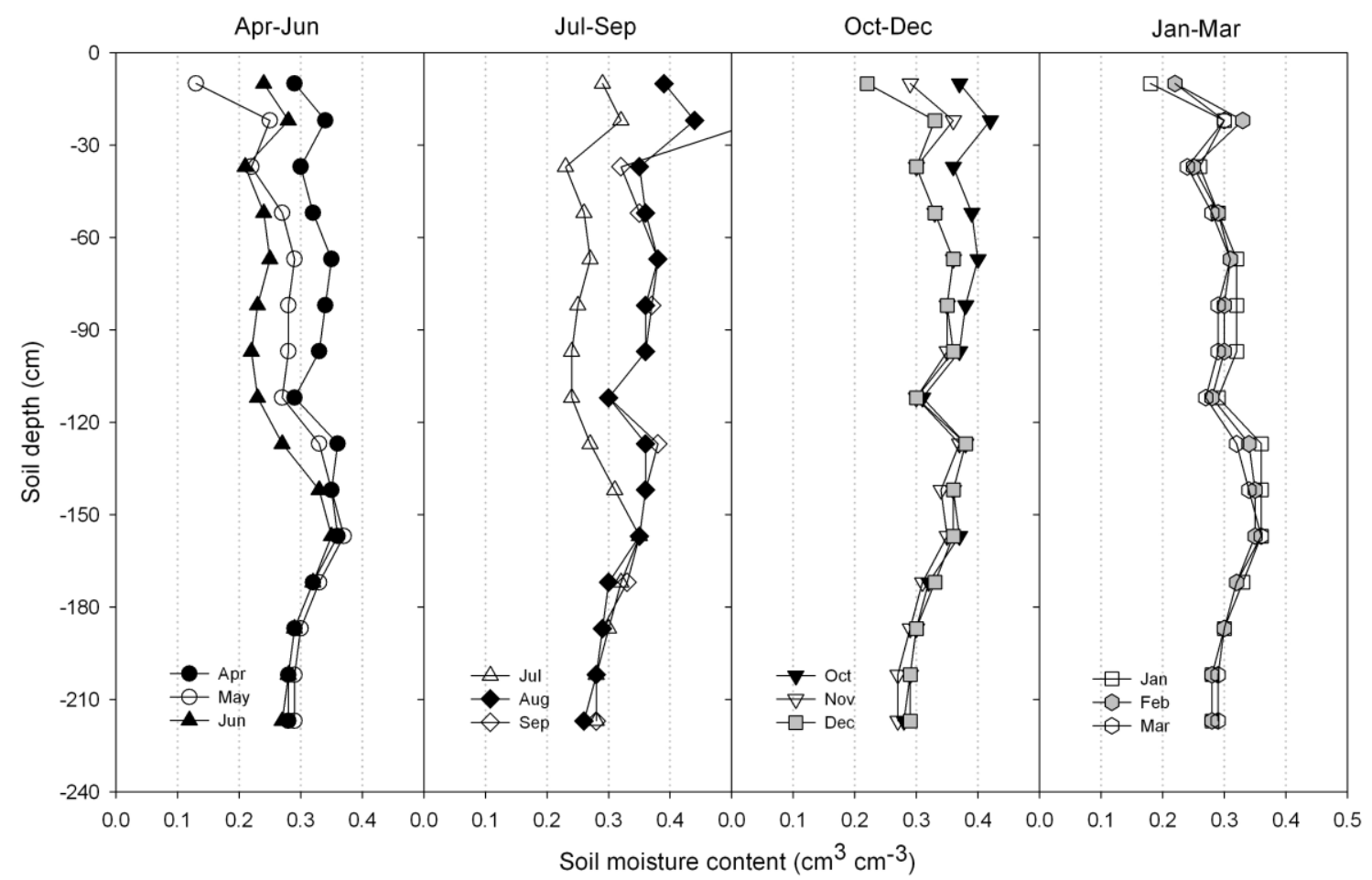

Figure 2a:

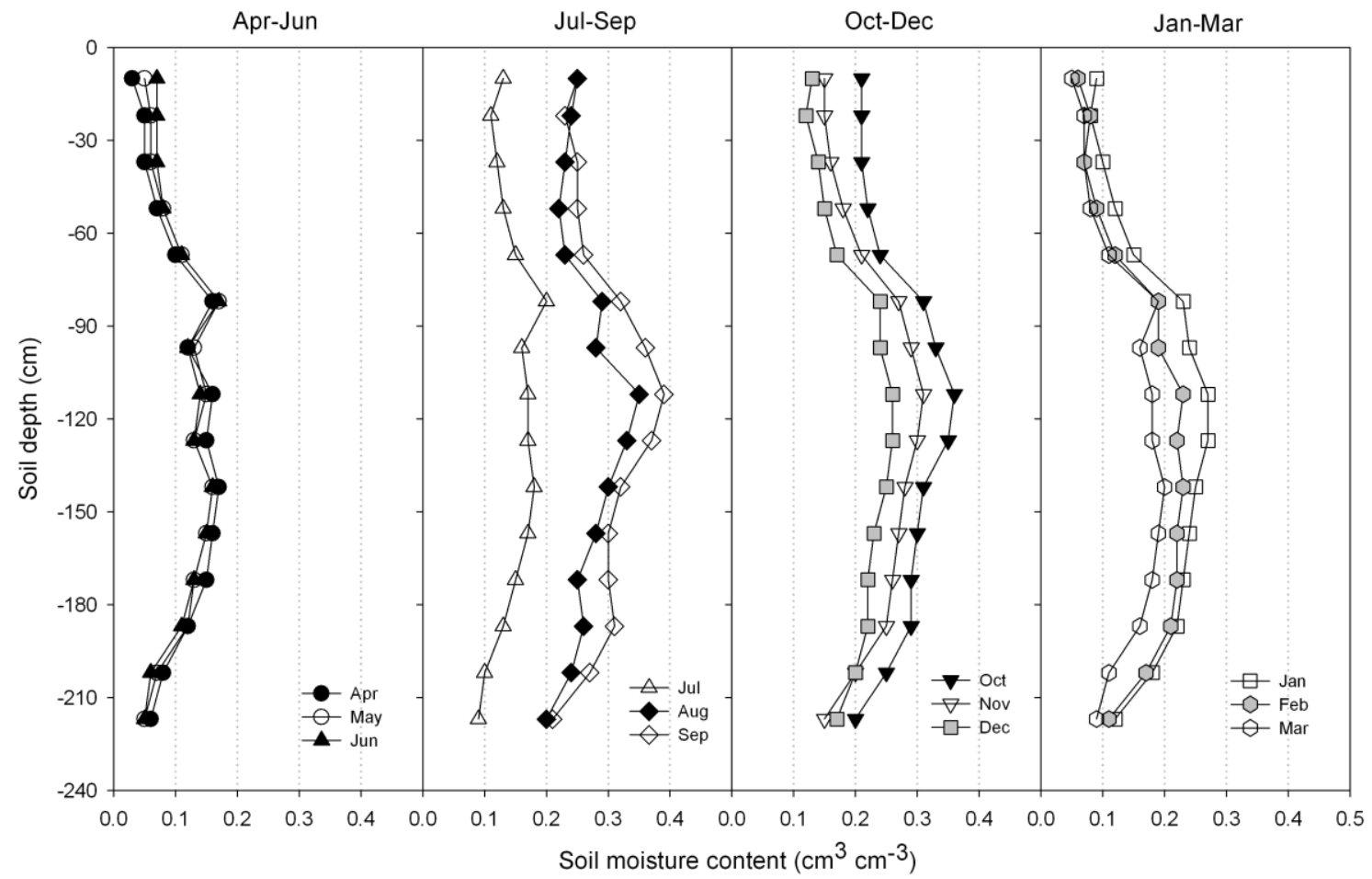

Figure 2b:

Figure 2a Depth wise soil moisture content during 12 months in Jatropha experimental field Figure $\mathbf{2 b}$ Depth wise soil moisture content during 12 months in Pongamia experimental field 

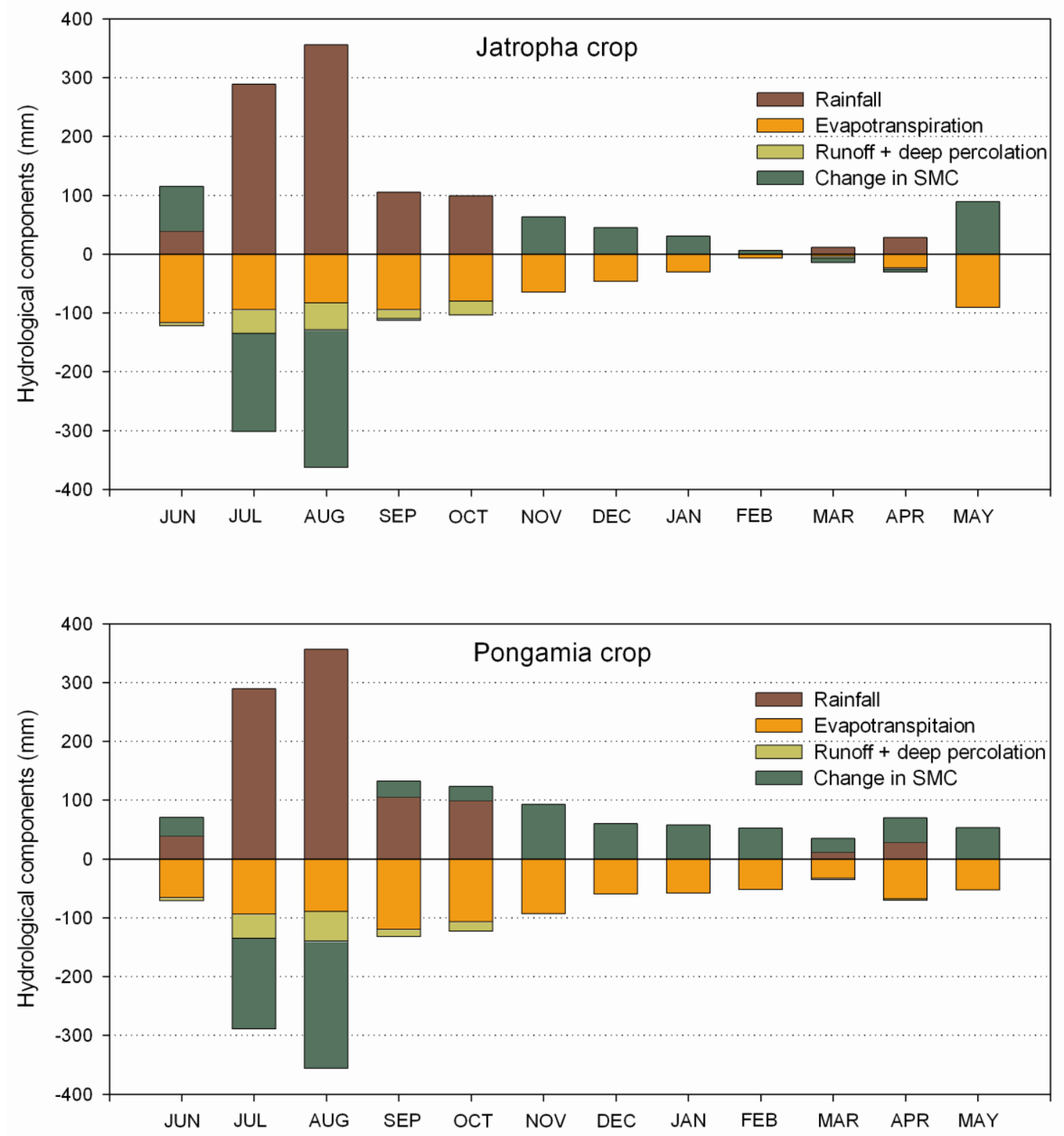

Figure 3 Monthly simulated water balance of Jatropha and Pongamia fields at ICRISAT for a selected normal year (2003-2004); the upper part of the graphs show the source of the water (rainfall and change in soil moisture content), and the lower part presents various sink components: ET, surface runoff, deep percolation, change in soil moisture content 